\title{
Recognition and management of children with increased lead absorption
}

\author{
J. JULIAN CHISOLM, JR AND DONALD BARLTROP
}

Baltimore City Hospital, USA, and Westminster Medical School, London

Childhood lead poisoning has been increasingly recognised in the USA where large-scale screening programmes detect some 40000 cases of undue lead absorption a year. This contrasts with data from the UK where about 100 cases are recognised each year. The situation in other countries is largely unknown, although small surveys have revealed cases from a wide variety of sources. These apparent discrepancies probably reflect differences in clinical awareness, the availability of practical screening tests, and differences in the definition of acceptable degrees of exposure.

Within the last few years practical and effective screening tests for the early detection of undue lead absorption have been developed, but these have not been generally introduced. They include the determination of lead and erythrocyte protoporphyrin (FEP) in microlitre samples of blood. These tests have provided evidence of undue lead absorption from previously unrecognised sources. Thus, dusts contaminated with lead derived from atmospheric deposition, industrial clothing, and degradation of paint films, have now been shown to be important contributory factors. Many children thus affected are asymptomatic, and classical childhood plumbism and encephalopathy at present are rare.

The identification of asymptomatic children has as its objective the institution of effective management in order to prevent serious poisoning and its consequences, and to diminish the potential risks of prolonged low level overexposure. While these risks have not been conclusively demonstrated, it has nevertheless been suggested that subtle neural and behavioural impairments may occur. Moreover, the existence of some children in the population with

Baltimore City Hospital, Maryland, USA

J. JULIAN CHISOLM JR, senior staff paediatrician

Department of Child Health, Westminster Medical School

London

DONALD BARLTROP, reader in child health
FEP values that are abnormally high due to lead is no longer considered acceptable.

\section{Sources}

Lead is an ubiquitous element with numerous industrial and domestic applications. Children are invariably exposed to lead in general environmental sources-such as food, water, air, dust, and soilbut they may also be exposed to specific and unusual sources including lead paint, lead fishing, curtain, and other weights ingested and retained in the stomach, or the fumes and dust generated by burning lead battery casings, or wood painted with lead pigment paint. Clinical lead poisoning usually occurs as a result of exposure to the second category of items.

General environmental sources. Each major component of the environment-food, water, air, dust, and soil-contributes to the child's total daily intake of lead. Although exposure to lead from these sources is negligible under ordinary circumstances, reports of excess environmental contamination from them are becoming more common. Table 1 lists lead contents for these sources, both under ordinary circumstances and under circumstances of excess environmental contamination.

Food is the principal source of lead for most children. Ordinary daily diets of infants and children may vary widely in lead content; however, limited data suggest that normal diets are associated with average blood lead (PbB) values of $20 \mu \mathrm{g} / 100 \mathrm{ml}(0.97 \mu \mathrm{mol} / \mathrm{l})$ whole blood or less (National Academy of Sciences/ National Research Council, 1976). More important is the question of contamination of food and drink with exogenous lead. Contamination may occur at the point of origin, during processing, or during preparation and serving at home. Sources of contamination at the point of origin include lead 
Table 1 Sources of lead in a child's environment

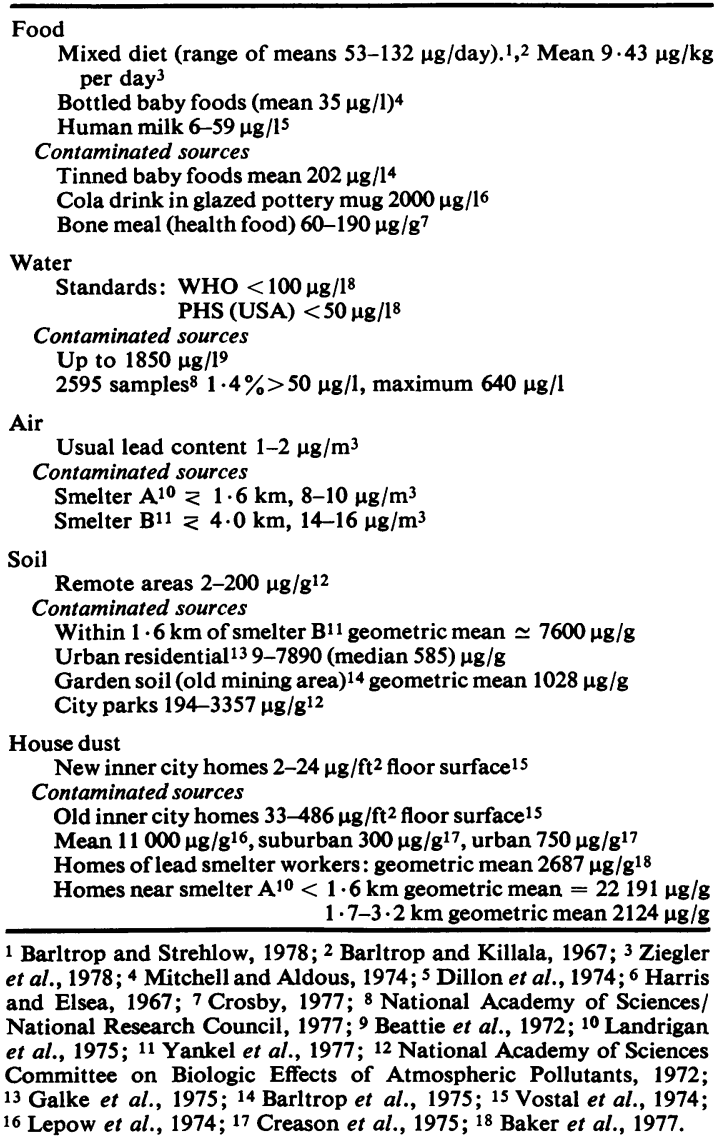

arsenate insecticides used on fruit trees, fertiliser made from sewage sludge, and exhaust fumes from cars and lorries from roads adjacent to gardens in which leafy green vegetables such as lettuces are grown. Even so, contamination by the use of lead solder to seal tins is more important. Mitchell and Aldous (1974) found upon examination of 256 tins that the contents of $62 \%$ contained $\mathrm{Pb}>100 \mu \mathrm{g} / \mathrm{l}$, $37 \%$ contained $>200 \mu \mathrm{g} / \mathrm{l}$, and $12 \%$ contained $>400 \mu \mathrm{g} / \mathrm{l}$. In similar foods in glass or aluminium containers, only $1 \%$ had lead levels $>200 \mu \mathrm{g} / \mathrm{l}$. Much more serious is the cooking and serving of food in ancient pewter or imperfectly glazed ceramic utensils. Milligram quantities of lead can be leached from such vessels, especially by acidic items (e.g. fruits, fruit juices, tomatoes, cider, wine, cola drinks, and soda). Fatal and nonfatal cases of encephalopathy in young children have been traced to the consumption of beverages from improperly lead-glazed vessels (Klein et al., 1970; Sitarz, 1975). Severe lead poisoning in 2 infants was traced to electric kettles with lead-soldered heating coils used to boil water for the infants' formulae ( $\mathrm{Ng}$ and Martin, 1977; Wigle and Charlebois, 1978). Human milk is reported to contain $\mathrm{Pb} 6-59 \mu \mathrm{g} / \mathrm{l}$ (Dillon et al., 1974). As lead is secreted in human milk, a nursing mother with increased lead absorption would be expected to produce milk with increased lead content. Lead poisoning has also been reported in people using bone meal as a dietary supplement (Crosby, 1977) and Chinese herbal medicines (Lightfoote et al., 1977).

Drinking water ordinarily contains only traces of lead; however, it may be contaminated if plumbosolvent soft waters of low $\mathrm{pH}$ are conveyed in lead pipes (National Academy of Sciences/National Research Council, 1977). Water collected at the tap serviced by 969 public water systems in the USA had an average lead content of $13 \cdot 1 \mu \mathrm{g} / \mathrm{l}$ and only $1.4 \%$ of 2595 samples contained more lead than the drinking water standard set by the US Public Health Service 1962 of $50 \mu \mathrm{g} / 1$ (McCabe et al., 1970). In the UK where soft water is more common, drinking water from approximately 1.7 million household exceeds the WHO limit of $\mathrm{Pb} 100 \mu \mathrm{g} / \mathrm{l}$ on the first flush sample. Values as high as $1800 \mu \mathrm{g} / \mathrm{l}$ have been reported (Beattie et al., 1972). Similar, but not as severe, contamination of drinking water has been reported in the north eastern USA (National Academy of Sciences/National Research Council, 1977).

The contribution of atmospheric lead to daily intake has been the subject of controversy. Urban air generally contains 1 to $2 \mu \mathrm{g}$ respirable lead $/ \mathrm{m}^{3}$ derived from numerous sources, including exhaust fumes from cars, industrial emissions, and the burning of fossil fuels (World Health Organisation, 1977). Pronounced local variations may occur in relation to stationary sources such as lead smelters (Table 1). Wide variations may also occur seasonally or because of thermal inversions. In London, for example, atmospheric lead concentrations near a road increased during the winter when thermal inversions are most common (D. Barltrop and C. D. Strehlow, unpublished data). For adults, it has been calculated that $\mathrm{PbB}$ will increase by $2 \mu \mathrm{g} / 100 \mathrm{ml}(0.097 \mu \mathrm{mol} / \mathrm{l})$ for each $1 \mu \mathrm{g} / \mathrm{m}^{3}$ in air (Chamberlain et al., 1978), but it is not yet known whether these values are directly applicable to children. Williams et al. (1933) traced an outbreak of severe lead poisoning to the burning of discarded battery casings in the home. More recently, symptomatic lead poisoning was reported in people burning, sanding, and scraping old lead while renovating old homes (Wolf, 1973; Feldman, 1978). Burning of newspaper 'logs' in domestic fireplaces was associated with increased lead absorption in an infant (Perkins and Oski, 1976). 
Household dust and soils can be contaminated by the powdering and flaking of old lead paint (Vostal et al., 1974), fallout from atmospheric pollution (Yankel et al., 1977), or by lead-bearing dust being carried into the home on the clothing of workers employed in the lead trades (Baker et al., 1977). The relative contribution to the total lead content of household dust from each of these sources is exceedingly difficult to determine (Bridbord, 1977). In one study in an urban area, Galke et al. (1975) found that $\mathrm{PbB}$ in children was related to soil lead which, in turn, was related to both automotive traffic density and leaded house paint. Table 2 shows the relationship between dust lead and blood lead level in 38 children aged between one and 6 years. This and other studies indicate that there is a significant correlation between household dust containing $<1000-1500 \mathrm{ppm}$ lead and $\mathrm{PbB}>40 \mu \mathrm{g}$ $(>1.93 \mu \mathrm{mol})$ in children. Domestic garden soils may also contain significant amounts of lead. Higher concentrations are generally found within a few metres of the house as a result of decomposition of external painted surfaces (ter Haar and Aronow, 1974; Galke et al., 1975). An increase in the geometric mean blood lead concentration of young children of approximately $8 \mu \mathrm{g} / 100 \mathrm{ml}(0.4 \mu \mathrm{mol} / \mathrm{l})$ was found in a district in which the mean soil lead concentration exceeded $10000 \mathrm{ppm}$ compared with a control district in which the soil lead content was $<1000$ ppm (Barltrop et al., 1975).

Specific and unusual high dose sources. The ingestion of lead-based household paint is without doubt the main source of serious paediatric lead poisoning (National Academy of Sciences Committee on Biologic Effects of Atmospheric Pollutants, 1972; National Academy of Sciences/National Research Council, 1976). Such paints may contain 1-70\% lead, so that tiny flakes contain a highly toxic dose (Fig. 1). Lead poisoning is most prevalent in old poorlymaintained houses in which there is flaking paint,

Table 2 Comparison of lead in household dust with blood lead in children of lead workers*

\begin{tabular}{lll}
\hline $\begin{array}{l}\text { No. of } \\
\text { children }\end{array}$ & $\begin{array}{l}\text { Children's blood } \\
\text { lead }(\mu \mathrm{g} / 100 \mathrm{ml} \pm S \mathrm{~S})\end{array}$ & $\begin{array}{l}\text { Dust lead } \\
\text { concentration }(\mathrm{ppm})\end{array}$ \\
\hline 18 & $21 \cdot 8 \pm 7 \cdot 8$ & $0-1000$ \\
5 & $41 \cdot 6 \dagger \pm 11 \cdot 1$ & $1000-2000$ \\
5 & $46 \cdot 2 \dagger \pm 21 \cdot 1$ & $2000-3000$ \\
4 & $65 \cdot 0 \dagger \pm 10 \cdot 4$ & $5000-6000$ \\
6 & $73 \cdot 3 \dagger \pm 34 \cdot 0$ & $7000-80000$ \\
\hline
\end{tabular}

*Employed in secondary lead smelter.

†Significantly $>$ mean level than in children exposed to $0-1000 \mathrm{ppm}$ level of lead in dust $(P<0.001)$.

Adapted from Baker et al. (1977).

Conversion: traditional units to $S I$-blood lead: $1 \mu \mathrm{g} / 100 \mathrm{ml} \approx 0.048$ $\mu \mathrm{mol} / 1$.

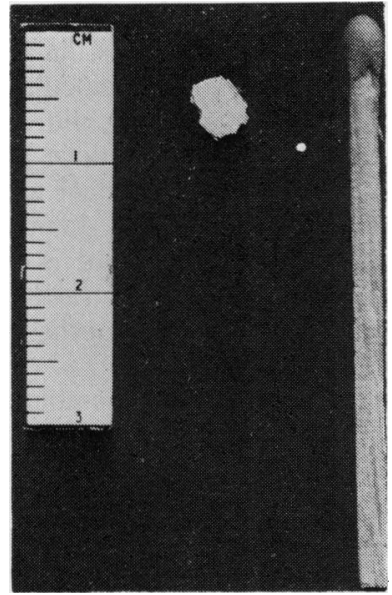

Fig. 1 Paint flake weighing $10 \mathrm{mg}$ containing $10 \%$ lead. $(1000 \mu \mathrm{g})$. Match and $\mathrm{cm}$ scale for comparison.

(Reproduced by kind permission of the Postgraduate Medical Journal)

and in families in which young children lack proper supervision. Sporadic cases also occur due to the ingestion of lead fishing weights, lead curtain weights, or lead shot (Seto and Freeman, 1964). Less common sources include jewellery painted with lead to simulate pearl, inhalation of fumes of leaded gasoline (Boeckx et al., 1977), cosmetics (Warley et al., 1968), decals* on cocktail glasses (Natelson and Fred, 1976), and hobbies that use ceramics or leaded stained glass. Although tetraethyl lead poisoning caused by sniffing gasoline is more common in teenagers, cases have also been reported in children under 12 .

\section{Metabolism and effects}

Metabolism. Among people with no unusual lead exposure, the total body lead burden may increase from $0.2 \mathrm{mg}$ at birth to $>200 \mathrm{mg}$ during life; however, the increase is limited almost entirely to increasing storage of lead in bone. The concentration of lead in soft tissues normally remains low and relatively constant throughout life (Barry, 1975). Lead incorporated into bone is virtually inert, metabolically speaking. The toxic effects of lead are related to increases in its concentration in the soft tissues. Although there are no data on dose-response for ingested lead in children, it is of interest to compare studies by Kehoe (1961) on chronic adult volunteer lead feeding with the information in children (Mahaffey, 1977). Kehoe found that raised levels of $\mathrm{PbB}$ to $80 \mu \mathrm{g}(3.9 \mu \mathrm{mol})$ and a likelihood of symptomatic poisoning could be induced after 3 or *A transfer (picture or design). 
4 months with a daily dose of $4 \mathrm{mg} \mathrm{Pb}$. From data on faecal lead, Barltrop and Killala (1967) and Chisolm and Harrison (1956) calculated that the comparable dose in young children is about $1 \mathrm{mg} /$ day-i.e. $25 \%$ of the adult dose. These intakes are equivalent on the basis of surface area, and both are about 10 times the normal dietary intake for adults and children. Because lead is slowly metabolised, soft tissue lead concentrations, including $\mathrm{PbB}$, decrease very slowly for months or years after the excessive intake has stopped.

Recent kinetic studies with a stable lead isotope $\left({ }^{204} \mathrm{~Pb}\right)$ in 5 healthy men suggest a 3-compartmental model for lead metabolism (Rabinowitz et al., 1976). The 2 smaller compartments, one of which is related to excretion of lead via urine and the other to excretion via other routes, consist of blood, soft tissues, and probably, a small exchangeable fraction of lead in bone. The mean lives of lead in these compartments are 35 and 40 days. Rabinowitz et al. (1976) estimate that the mean life of lead in bone is about 27 years. Comparable long-term data on steady-state kinetics are not available for young children. Multiple 3-day balances in American infants of under 2 years show wide variation in lead intakes from normal infant foods $(0 \cdot 83$ to $22 \cdot 61$ $\mu \mathrm{g} / \mathrm{kg}$ per day; mean, $9.43 \mu \mathrm{g} / \mathrm{kg}$ per day) (Ziegler et al., 1978). While net retention for all studies averaged $11 \%$ of intake, retention increased to $32 \%$ when dietary intake exceeded $\mathrm{Pb} 5 \mu \mathrm{g} / \mathrm{kg}$ per day. Retention of lead also showed a weak inverse correlation with dietary calcium. The retention of lead by children varies and many children in the short term may be in negative lead balance (Barltrop and Strehlow, 1978). A high incidence of suboptimal dietary intake of calcium was reported in children with increased lead absorption (Mahaffey, 1977; Sorrell et al., 1977). A significant decrease in serum 25-hydroxy vitamin $\mathbf{D}$ was reported in children with increased lead absorption (Sorrell et al., 1977; Strehlow and Barltrop, 1978). These clinical studies are consistent with studies in animals which indicate that deficient intake of calcium enhances absorption, retention, and toxicity of lead (Barltrop and Khoo, 1975; Barton et al., 1978; Goyer, 1978). Other experimental studies show that deficient dietary intakes of iron, copper, zinc, and selenium, as well as excessive dietary intake of fat, also increase absorption, retention, and toxicity of lead (Chisolm, 1978). Of interest is the observation that dietary iron in excess of requirements in rats may decrease rentention of lead (Mahaffey et al., 1978).

Effects. In man, the principal target organs for lead are the erythroid cells of the bone marrow, the central and peripheral nervous systems, and the kidney. The inhibitory effects of lead on erythropoiesis are reversible; however, severe acute or chronic clinical lead poisoning may be followed by irreversible injury to the nervous system and kidney. Scattered case reports suggest that acute clinical lead poisoning with $\mathrm{PbB}>100 \mu \mathrm{g}(>4.8 \mu \mathrm{mol})$ may also be associated with impaired uptake of iodine by the thyroid, impairment of the reninaldosterone system, and ECG changes compatible with myocarditis: the effects are apparently reversible (National Academy of Sciences Committee on Biologic Effects of Atmospheric Pollutants, 1972). The varied cellular effects, which are demonstrable experimentally in vitro, are beyond the scope of this report, but are reviewed elsewhere (Vallee and Ulmer, 1972; Granick et al., 1978). The classical concepts of toxicology have been adapted to evaluate lead exposure, absorption, and effect in human populations (Nordberg, 1976) and are summarised elsewhere (Chisolm et al., 1975). In experimental toxicology, the concentration of lead and its effects may be measured directly in affected cells and cell components. In human studies, $\mathrm{PbB}$ and chelatable lead* are used as indicators of its concentration in the tissues (internal dose), while various metabolites in blood and urine serve as indicators of its effect in the tissues.

Increase in $\delta$-aminolaevulinic acid in urine (ALAU) is one of the biochemical indicators of lead's inhibitory effects on heme synthesis. The curvilinear dose-effect relationship between $\mathrm{PbB}$ and ALAU is such that ALAU increases very sharply as $\mathrm{PbB}$ rises above $40-50 \mu \mathrm{g}(1 \cdot 9-2 \cdot 4 \mu \mathrm{mol})$. The rate of increase is so sharp that ALAU may vary from normal to 5 times greater than normal within the rather narrow 50-60 $\mu \mathrm{g}(2 \cdot 4-2 \cdot 9 \mu \mathrm{mol})$ range in $\mathrm{PbB}$ (Fig. 2). Similarly, clinical response also varies, as the full clinical spectrum from no symptoms to fatal acute encephalopathy in children may be found within the PbB range of 100-200 $\mu \mathrm{g} \mathrm{(4 \cdot 8-9 \cdot 7}$ umol) (Table 3). Clearly, responses cannot be ascertained from $\mathrm{PbB}$ alone.

New definitions of the terms 'critical organ' and 'critical effect' relative to lead have been proposed (Nordberg, 1976) and have important implications for preventive medicine. Derangement of $\mathrm{Hb}$ synthesis in the erythroid cells of the bone marrow is now considered the critical or first adverse effect. Current preventive health policies rest on the assumption that intervention on the basis of biochemical evidence of derangement of $\mathrm{Hb}$ synthesis will suffice to prevent the more serious and possibly long-term adverse effect of lead in the nervous system and kidney. It should be borne in mind,

*Chelatable lead=quantity of lead excreted in urine after standardised dose of CaEDTA or D-penicillamine. 


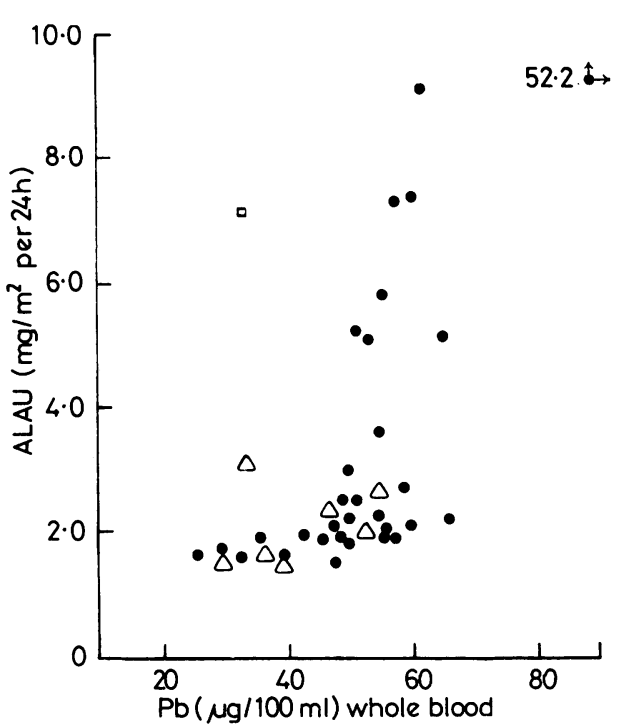

Fig. 2 Relationship between $P b B$ and $A L A U$ in children. For children with $P b B$ between 8 and $30 \mu g$, normal daily excretion averages $1.1 \pm 0.4 \mathrm{mg} A L A U / \mathrm{m}^{2}$ per $24 \mathrm{~h}$ (upper limit of normal $2 \cdot 3 \mathrm{mg} A L A U / \mathrm{m}^{2} \mathrm{per}$ 24 h) (Chisolm et al., 1976). Daily output of $A L A U$, which is related to surface area in children, increases sharply as $\mathrm{PbB}$ increases above $50 \mu \mathrm{g}$; however, there are pronounced differences in $A L A U$ among individuals with $\mathrm{PbB}$ in the 50-60 $\mathrm{g}$ range. The two anomalous cases shown as $\square$ and $\triangle$ had sickle cell disease and sickle cell trait, respectively.

Table 3 Relationship between blood lead concentration and symptoms of plumbism in children*

\begin{tabular}{llll}
\hline Clinical group & \multicolumn{3}{c}{ Blood lead concentration $(\mu \mathrm{g} / 100 \mathrm{ml})$} \\
\cline { 3 - 4 } & & Median & Range \\
\hline Acute encephalopathy & & & \\
$\quad$ Fatalities & 98 & 295 & $138-750$ \\
$\quad$ Survivors & 99 & 270 & $88-1,310$ \\
$\begin{array}{l}\text { Acute plumbism (non- } \\
\text { encephalopathic) }\end{array}$ & 40 & 135 & $63-450$ \\
$\begin{array}{l}\text { Increased lead absorption } \\
\quad \text { (? clinical symptoms) } \dagger\end{array}$ & 46 & 85 & $60-300$ \\
\hline
\end{tabular}

*Adapted from National Academy of Sciences Committee on Biologic Effects of Atmospheric Pollutants (1972), as compiled from reports of Chisolm and Harrison (1956), Chisolm (1962, 1968), and Baltimore City Health Department.

†Although some children in this group had nonspecific symptoms compatible with plumbism, they also had other conditions which give rise to the same symptoms, making clinical diagnosis uncertain.

For conversion to SI units see footnote to Table 2.

however, that biochemical indicators of lead's effects on heme synthesis in erythrocytes are extraordinarily sensitive and not entirely specific for lead: FEP is raised in both iron deficiency and increased lead absorption, and $\delta$-aminolaevulinic acid dehy- dratase (ALAD) is a zinc-dependent enzyme inhibited by lead (Chisolm, 1978).

Heme synthesis in bone marrow

All cells synthesise heme for their own hemoproteins $(\mathrm{Hb}$, myoglobin, catalase, cytochromes, P-450, etc.) via a common metabolic pathway. Experimental data show that lead interferes with this process in all organs so far studied; however, the erythroid cells of the bone marrow are the most sensitive (Moore, 1975; Nordberg, 1976). There are 6 major enzymatic steps in the formation of heme. In lead-poisoned adults, increased activity of $\delta$ aminolaevulinic acid synthetase, partial inhibition of ALAD, coproporphyrinogen oxidase, and ferrochelatase has been demonstrated (Wada et al., 1972; Campbell et al., 1977). These enzymatic changes account for the pattern of metabolites found in blood and urine, which is pathognomonic for lead; namely, decreased in vitro activity of ALAD in circulating erythrocytes, increased FEP, increased excretion of ALAU and coproporphyrin (CPU), and normal or nearly normal excretion of porphobilinogen and uroporphyrin in urine. Excess lead also impairs the uptake and use of iron, as well as the synthesis of globin in developing erythrocytes. In children the circulating erythrocytes are hypochromic and microcytic, and reticulocytosis is sometimes found. The morphology of the peripheral blood in children with plumbism is virtually identical with that found in iron deficiency, a condition with which plumbism is often associated. Lead also impairs the activity of $\mathbf{5}^{\prime}$-pyrimidine nucleotidase, which accounts for the basophilic stippling of erythrocytes associated with severe and chronic plumbism (Valentine et al., 1976). When $\mathrm{PbB}>60$ $\mu \mathrm{g}, \mathrm{Hb}$ and haematocrit are significantly reduced (Rosen et al., 1974; Landrigan et al., 1976). Pueschel et al. (1972) and Betts et al. (1973) have reported an increasing frequency of reduced $\mathrm{Hb}$ when $\mathrm{PbB}>40$ $\mu \mathrm{g}$. These differences are probably attributable to differences in the prevalence of iron deficiency in the populations of children studied. The $\mathrm{PbB}$ threshold for increase in ALAU in children is between 40 and $50 \mu \mathrm{g} \mathrm{Pb}$. Although the threshold for FEP in children is apparently lower, the increase is generally slight-up to about $30 \mu \mathrm{g} \mathrm{Pb}$-above which it increases exponentially (Stockman et al., 1975; Hanna et al., 1976; World Health Organisation, 1977). FEP may also be increased in iron-deficient children with $\mathrm{PbB}<30 \mu \mathrm{g}(<1.5 \mu \mathrm{mol})$ (Stockman et al., 1975; Koller et al., 1978; Strehlow and Barltrop, 1978).

\section{Kidney and bone}

Clinical lead poisoning may be associated with both 
acute and chronic effects in the kidney. In children with acute encephalopathy and $\mathrm{PbB}>150 \mu \mathrm{g}$ $(7 \cdot 2 \mu \mathrm{mol})$, the full Fanconi triad (hyperaminoaciduria, glycosuria, and hyperphosphaturia) in the presence of hypophosphataemia has been reported (Chisolm, 1962). The Fanconi triad is reversible. Children with a history of clinical plumbism during the preschool years in the USA have not shown evidence of residual renal injury in adolescence or early adult life (Tepper, 1963; Chisolm, 1970). This experience differs from that in Australia where an increased frequency of late lead nephropathy was reported (Nye, 1929; Henderson and Inglis, 1957). Emmerson (1968) described the syndrome as characterised by progressive loss of renal function, often with hyperuricaemia and saternine gout, terminating with renal failure. Some of these patients were also mentally retarded and had pes cavus deformity due to old peripheral neuropathy. In the Australian children, symptomatic episodes of plumbism extended well beyond the preschool years, up to 10 to 12 years. It seems likely that prolonged poisoning was an important factor in the irreversible renal injury sustained by the Australian children.

The bands of increased density at the metaphyses of growing long bones characteristic of lead poisoning in children are generally limited to those who have sustained $\mathrm{PbB}>50$ to $60 \mu \mathrm{g}$ (Betts et al., 1973). Although these $x$-ray changes are generally called 'lead lines', a major factor is distortion of bone architecture and increased mineral deposition caused by lead. Their presence suggests that one of the body's important compensatory mechanismsstorage of excess lead in bone-is being impaired.

\section{Neurological and behavioural effects}

Acute lead encephalopathy is the most severe clinical form of lead poisoning. Pathologically, it is characterised by extensive cerebral vasculopathy and massive oedema of the brain (Clasen et al., 1974). It is most common during the summer months in children of under 3. Before the advent of chelating agents, $65 \%$ of severe cases terminated fatally. In recent years, chelation treatment with a combination of BAL and CaEDTA has reduced mortality to less than 5\% (Coffin et al., 1966; Chisolm, 1968). When chelation treatment is begun after the symptoms of acute encephalopathy appear, the incidence of severe permanent sequelae-such as mental retardation, seizure disorders, blindness, and hemiparesis-is estimated at 25 to $50 \%$, even if abnormal re-exposure is promptly stopped (Chisolm and Harrison, 1957; Byers, 1959; Chisolm, 1973). Byers and Lord (1943) reported that 19 of 20 children with at least one symptomatic episode of plumbism subsequently did poorly in school, despite the fact that standard psychometric tests indicated normal intelligence. Failure in school was attributed to behavioural disorders, lack of attention, perseveration, and visual-motor impairment. In a similar group of 425 children, Perlstein and Attala (1966) found that $39 \%$ sustained severe neurological sequelae. Although data on $\mathrm{PbB}$ are not systematically given, the data in Table 3 suggest that they were describing the chronic course and outcome in children in whom $\mathrm{PbB}$ repeatedly exceeded 80 to $100 \mu \mathrm{g}$. In the USA, screening data currently reported to the Center for Disease Control indicate that 3 to $20 \%$ of preschool children have increased lead absorption, as shown by $\mathrm{PbB}$ in the 30 to $80 \mu \mathrm{g}$ range. Most are asymptomatic, while mild nonspecific symptoms compatible with early plumbism are reported in a few. In children living near primary smelters (Landrigan et al., 1975) or in the homes of workers who carry fine particulate lead home on their clothing (Baker et al., 1977), the proportion of children with increased lead absorption is somewhat higher. Even so, most are asymptomatic. Whether such children are at significant risk for subtle, but significant neurobehavioural impairment has aroused much concern. During the postnatal phase of rapid neurodevelopment, which in children extends from birth to 2 or 3 years, the brain may be especially vulnerable to nutritional and toxic insults (Dobbing and Smart, 1974). Evidence is still incomplete and clinical studies have given conflicting results. Experimentally, lead can be shown in vitro to inhibit the calcium-mediated release of neuro-transmitters, cause demyelinisation of the axon, impair oxidative metabolism in the brain, and impede transmission at the neuromuscular junction (Granick et al., 1978). Animals dosed with lead during the phase of rapid postnatal neurodevelopment showed slowed learning (Brown, 1975), maturational delay (Grant et al., 1976), and scotopic defects (Bushnell et al., 1977). During infancy, $\mathrm{PbB}$ values in the range of 40 to $80 \mu \mathrm{g}$ were reached in these experiments, although the deficits were not shown until after PbB levels had returned to normal. Thus, the experimental data suggest that increased lead absorption during the phase of rapid neurodevelopment may induce later neurobehavioural deficits. Some animal studies are confounded by inadequate nutritional controls (Barltrop and Khoo, 1975; Reiter et al., 1975). In view of other experimental studies which indicate that deficiencies of iron and zinc may have similar subtle adverse neurobehavioural effects, resolution of this question still awaits appropriately designed studies.

Clinical studies have also given conflicting results. Lansdown et al. (1974) and McNeil et al. (1975) did 
not find deficits at school age, and Kotok et al. (1977) attributed the deficits they found to preexisting factors. Conversely, Albert et al. (1974), Rummo (1974), and de la Burdé and Choate (1975) did find deficits at school age which they attributed to lead. The only workers who have conducted a study prospectively from birth to 8 years of age are de la Burdé and Choate (1975), and their findings are similar to those of Byers and Lord (1943), inasmuch as poor performance in school was also attributable primarily to behavioural problems. These various studies suggest that no significant impairment has been found in children from higher socioeconomic classes who were well nourished and who generally had $\mathrm{PbB}<50 \mu \mathrm{g}$. Positive findings have been in children from the lowest socioeconomic class in deteriorated urban areas whose source of lead was paint, and who sustained $\mathrm{PbB}>50-60 \mu \mathrm{g}$, and in whom poor nutritional status was strongly suspected. Neurobehavioural impairment at school age has been related to raised levels of lead in shed deciduous teeth (Needleman et al., 1978); however, these data do not give a retrospective estimate of earlier blood and soft tissue lead levels. David et al. (1972) were the first to suggest that asymptomatic increased lead absorption might be one of the aetiological factors in hyperactivity in children. This provocative hypothesis has yet to be tested adequately. Initially, experimental studies in which high doses of lead were used in suckling animals seemed to confirm the hypothesis of David et al. (1972); however, subsequent studies with lower doses have generally not resulted in increased locomotor activity (e.g. Reiter et al., 1975).

Peripheral neuropathy is rare in children. Among the 15 cases recently reported from America, 7 were in children with sickle cell disease (Anku and Harris, 1974; Erenberg et al., 1974). This striking clinical observation may be important, inasmuch as sickle cell disease is apparently associated with secondary zinc deficiency (Prasad et al., 1975), and studies in animals indicate that zinc is protective against lead.

\section{Management}

Clinical management. Paediatric intervention should be started in the presymptomatic phase in order to lessen the risk of serious injury to the nervous system. Indeed, most referrals today are likely to be asymptomatic children who have been identified in screening programmes, epidemiological surveys, or as housemates of an index case of poisoning. The nature of the exposure (see Environmental management), as well as the age of the child and his nutritional, genetic, developmental, psychosocial, and behavioural status should be weighed in making a plan of management tailored to his needs. Children under 3, in whom pica is common (Barltrop, 1966), and in whom the rapid postnatal phase of neurodevelopment is not yet complete, usually need closer follow-up than older children. Adequate dietary intakes, particularly of calcium, iron, and zinc must be assured, while excessive dietary fat is to be avoided. Response to medicinal iron, which is often required, can be monitored by serial FEP tests (Fig. 3).

For those who are intolerant of milk, 'lactosefree' milk products, or an alternative source, will be necessary to ensure an adequate calcium intake. Clinical experience and the occurrence of zinc deficiency suggest that those with a sickling disease (Hb SS, SC, or S-thal) have a higher susceptibility to lead and so should receive priority for transfer to a 'low-lead' environment. Mentally retarded children, in whom chronic pica is prevalent, should receive $\mathrm{PbB}$ and FEP tests periodically as part of their regular health care, even if initial tests give normal results.

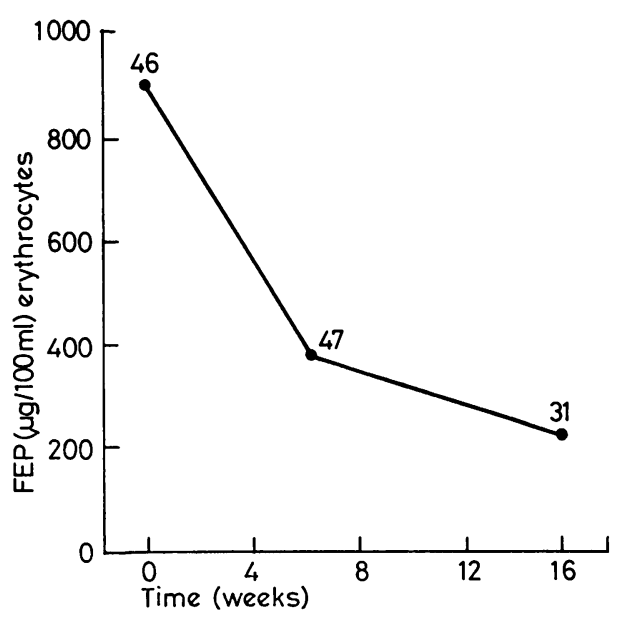

Fig. 3 Combined influence of iron deficiency and increased lead absorption on erythrocyte protoporphyrin (FEP). Line connecting points shows trend in FEP, while numbers adjacent to points show PbB values. Clinical history and additional data (serum $F E=21 \mu \mathrm{g} / 100 \mathrm{ml}$; $(3.76 \mu \mathrm{mol} / \mathrm{l}) ;$ TIBC $=544 \mu \mathrm{g}(97.14 \mu \mathrm{mol} / \mathrm{l})$; $\%$ saturation $=3.9 \%$ ) indicated deficient dietary intake of iron and residence in a dilapidated old house. During the first 7 weeks of treatment with iron, FEP decreased from 900 to $400 \mu \mathrm{g} / 100 \mathrm{ml}$ erythrocytes, and haematocrit increased substantially, although $\mathrm{PbB}$ remained unchanged. The family then moved from an old house to public housing in Baltimore, USA, where the use of lead-containing paints has been prohibited for the last 40 years. Iron treatment was continued and both $P b B$ and $F E P$ decreased further. 
The term pica refers to the magpie, a bird of both capricious and voracious appetite. The habit of pica may be defined as the repetitive search for and ingestion of nonedible items. In children, it starts at about 12 months and occurs in about half of one- to 3-year-old children (Barltrop, 1966). Its aetiology is not understood. Lourie et al. (1963) considered pica an important symptom of familial stress and disorganisation, with resultant lack of mothering. Success in ameliorating a child's pica often depends on the degree to which such family problems can be resolved.

In heavily contaminated areas, periodic testing throughout the preschool years is indicated. A child with increased lead absorption should be checked every 3 months for at least a year until $\mathrm{PbB}$ and FEP steadily decrease and stabilise at or near the normal range, indicating satisfactory abatement of hazards and probable diminution of pica. Sometimes initial clinical evaluation may suggest the need for follow-up, even if the initial $\mathrm{PbB}$ levels are normal, as an infant with pica may subsequently gain access to a hazardous lead source

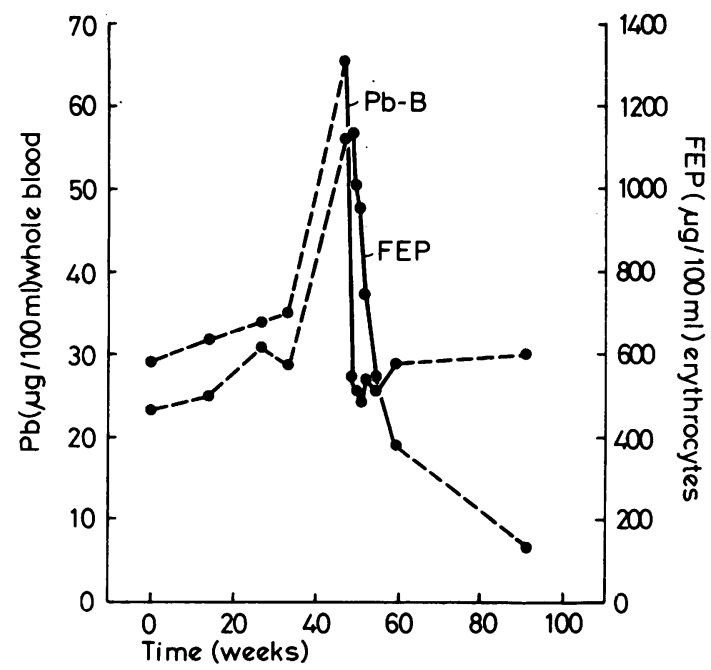

Fig. $4 P b B$ and FEP in an iron-deficient infant with indiscriminant pica.

Initial data showed residence in safe housing, normal lead absorption, and iron deficiency in a 12-month-old infant; however, a positive history of pica, visits to relatives in poor housing, and a working mother indicated the need for prolonged follow-up. Sharp rise in $\mathrm{PbB}$ and FEP coincided with relegation of the infant's care to young irresponsible relatives during the summer. Patient was treated (solid portion of line) in hospital with chelating agents, dietary correction, medicinal iron, behavioural management to lessen pica, and return to safe housing area.
(Fig. 4). Reigart and Whitlock (1976) found that a raised level of FEP, together with normal or minor increase in $\mathrm{PbB}$ is often predictive in young children of subsequent increase in $\mathrm{PbB}$ to potentially hazardous levels. The renovation of old leaded dwellings is hazardous not only for workmen (Feldman, 1978), but especially for young children who can experience a sharp rise in lead absorption (Fig. 5), even to symptomatic levels. Young children and pregnant women should seek residence elsewhere-night and day-until renovation is complete and the debris removed from the premises, an admonition not always heeded. The data in Fig. 5 illustrate another common occurrence; incomplete abatement of residential lead hazards with a spike in $\mathrm{PbB}$ in the child on return home.

While removal of lead from the child's environment is the key to successful clinical management, selective use of chelating agents can be a valuable adjunct. Three agents are used: edathamil calcium disodium (CaEDTA), 2, 3-dimercapto-1-propanol (BAL), and D-penicillamine (PCA). According to principles described elsewhere (Chisolm, 1968), the greater the physician's estimate of soft tissue lead

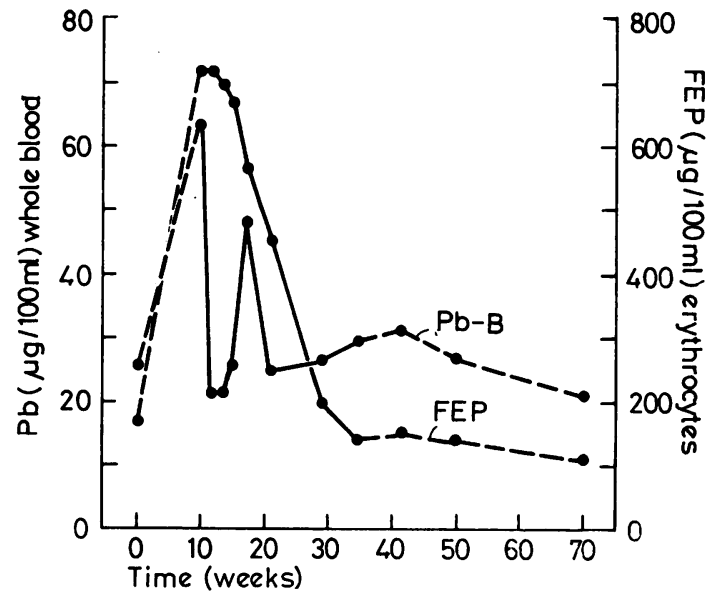

Fig $5 P b B$ and FEP changes in an infant during deleading of an old home.

The infant remained in the home during burning, scraping, and sanding of old lead-bearing paint. Both $\mathrm{PbB}$ and FEP levels increased dramatically during a fortnight of intense exposure. The infant was placed in hospital and treated with chelating agents, medicinal iron, and prophylactic amounts of copper and zinc. A rise in PbB from 22 to $47 \mu \mathrm{g}$ (1.06 to $2 \cdot 3 \mu \mathrm{mol})$ during fortnight immediately after discharge indicated incomplete hazard abatement. Family thereupon moved to modern 'lead-free' public housing. $P b B$ decreased promptly, while FEP continued to decrease. 
concentrations, the higher the initial dosage of chelating agents should be. Conversely, because of the curvilinear relationship between $\mathrm{PbB}$ and chelatable lead, arithmetic decreases in $\mathrm{PbB}$ are associated with exponential decreases in the amount of lead mobilised and excreted in the urine (Chisolm et al., 1976). It follows that their use in children with slightly increased soft tissue lead concentrations may be of such limited benefit as to be outweighed by the fact that these agents also remove substantial amounts of zinc and other trace metals which are protective against the toxicity of lead. Parenteral CaEDTA and BAL are considered primary drugs, while oral PCA serves well as a secondary sustaining agent if long-term treatment appears warranted and a low lead environment can be found for the child. Under no circumstances should chelating agents be given while excess lead intake continues. Patients on PCA must be closely monitored for renal (nephrotic syndrome) and haematological reactions (especially neutropenia). CaEDTA is a nonmetabolisable drug which is excreted exclusively by glomerular filtration. Fatal reactions have occurred when its use is continued in anuric patients. CaEDTA and PCA should not be used in asymptomatic or mildly symptomatic patients with intercurrent renal disease. BAL is contraindicated in patients with acute hepatocellular injury and in males with G6PD deficiency. These and other precautions are described more fully elsewhere (Chisolm, 1968; United States Public Health Service, 1978). Details of drug dosage and the treatment of acute encephalopathy are given in the Appendix.

The use of chelation treatment in asymptomatic or questionably symptomatic children with increased lead absorption is controversial, particularly the long-term oral use of PCA. The retrospective study of Albert et al. (1974) suggests that chelating agents in such cases may reduce the prevalence and severity of the neurobehavioural sequelae of early childhood plumbism. For children with $\mathrm{PbB}$ in the 30-50 $\mu \mathrm{g}$ range, correction of nutritional deficits and steps to reduce exposure, including stringent dust control in the home, should suffice. A disproportionate increase in FEP (Fig. 3) is suggestive of concurrent iron deficiency which should be corrected. An overview of current experimental data and studies on humans suggests that the combination of $\mathrm{PbB}>50-60 \mu \mathrm{g}$ and FEP $>300 \mu \mathrm{g} / 100 \mathrm{ml}$ erythrocytes in a child under 2 , and $>500 \mu \mathrm{g} / 100 \mathrm{ml}$ $(8.90 / \mu \mathrm{mol} / \mathrm{l})$ erythrocytes in a child over 2 , probably constitute reasonable clinical indications for at least brief courses of chelation treatment. The indication is further strengthened if long-bone $x$-rays are positive for 'lead lines'. The unresolved question is whether or not $\mathrm{PbB}$ concentrations sustained $>50-60 \mu \mathrm{g}$ over a period of months or years, even in the absence of continued abnormal ingestion, carries a significant risk for CNS injury.

Lead poisoning and increased lead absorption must be treated as chronic disorders. Often, the doctor, environmental hygienist, public health nurse, and medical-social service personnel have to work as a team. In certain areas of the USA, lead poisoning is a reportable disorder. Children surviving encephalopathy may require long-term management for seizure disorders, gross behavioural aberrations, and special school placement. For children who must perforce live in substandard housing, adequate nutrition may improve their resistance to lead. The effectiveness of any tentative long-term management is best judged by the child's biological response. Satisfactory control of emissions from stationary sources will be followed by decreases in $\mathrm{PbB}$ in the nearby population (Yankel et al., 1977).

Environmental management. The objectives of environmental management after the discovery of a case of excessive exposure to lead are twofold: (1) the prevention of re-exposure of the child and (2) the protection of other individuals who may be currently or subsequently exposed. This means that the identified source must be removed or at least measures taken to render it unavailable to young children.

\section{Domestic sources}

The most common sources in the home are accessible painted surfaces. The ideal solution is the complete removal of all lead-containing paint accessible to children and its replacement by an appropriate lowlead paint (lead-free) intended for interior use. Although legal provisions to enforce such action are available in some parts of the USA, this is not universal. Much depends on the ownership of the home, the attitude of local housing authorities, and the socioeconomic status of the family. Substantial amounts of fine particulate lead may be released during the course of remedial work, and these may be sufficient to cause significant additional burdens for children who remain resident in the home during renovations (Fig. 5). It is important that all preexisting paintwork be removed, and that the house is not merely redecorated with an additional layer of paint. Other temporary measures may include accessible painted surfaces being covered with an adhesive plastic material (United States Public Health Service, 1978).

Other domestic sources including glazed ceramics, toys, and surma*, (Table 1) should be controllable by simple advice and removal. Similarly, industrial clothing contaminated with lead should never

*Cosmetic used by Asians which sometimes contains lead sulphide. 
enter the home, although this may be difficult to enforce. The lead hazard of some industrial processes is not always appreciated (Gafafer, 1966). If heavy contamination of clothing occurs, the only solution is to ensure that the worker has the opportunity of bathing and changes his shoes and clothing at the workplace at the end of each shift. In addition, facilities for the laundering of industrial clothing must be available at the place of work, rather than in the home. Domestic sources of lead may result in heavy contamination of household dust on the floor and in the upholstery of furniture. If this has occurred, then as complete removal as possible of dust should be undertaken, using a vacuum-operated device.

Contaminated drinking water is usually the consequence of lead plumbing or storage tanks in an area where the water has a high degree of plumbosolvency. The only immediate solution is to provide an alternative supply from a less hazardous source, although the exposure may be mitigated by merely flushing the system for several minutes before use. This is particularly important after prolonged periods in which the water has been static in the delivery system, for example, in the early morning. The only ultimate solution is the removal of lead from the delivery system. While this may be possible for an individual family with a localised source, for example, an improperly soldered joint in a copper pipe or an imperfectly manufactured electric kettle, it may not be immediately applicable if the use of lead in the delivery system is extensive. Thus, in the UK, it has been estimated that the cost of meeting the WHO 'European' standard of $100 \mu \mathrm{g} / \mathrm{l}$ would be of the order of $£ 1000$ million. In this context, it should be noted that in the US, a water standard of $25 \mu \mathrm{g} / \mathrm{l}$ has been suggested (National Academy of Sciences/National Research Council, 1977). From a prophylactic standpoint, effective measures may require action at a national rather than a local level. Such measures may include introducing regulations governing the import, manufacture, or sale of leadbased cosmetics, toys, ceramic ware, paint, and graphic materials liable to be used by children at home or in educational establishments. There is little international agreement concerning such regulations. In the USA, the lead content of paints for domestic use has been severely restricted and a regulation restricting this to $0.06 \%$ has been promulgated, whereas in the UK a value of $1.0 \%$ is still permitted $(0.5 \%$ for toys and nursery furniture).

\section{Nondomestic sources}

Problems arising outside the home are only likely to be found in relation to industrial activities either current or defunct. This may result from direct access to tips or mine tailings of high lead content or dispersion of lead-contaminated dusts from their surface. In addition, lead may be dispersed in the atmosphere as respirable particulate material, the impact of which will depend on local topography and climatic conditions. In such cases, whole communities rather than individuals are likely to be affected and the solutions require the collaboration of several agencies. It is often difficult to identify the routes of transmission of lead in such circumstances or indeed to assess their relative significance. Immediate measures should depend on the severity of the cases. In the event of exposures of sufficient degree to result in frank plumbism, the only ethical choices are either the evacuation of the community or the immediate cessation of emissions. Ideally, atmospheric dispersion from many industrial sources can be substantially diminished by the introduction of effective baghouse (filtration) equipment. Reentrainment of lead by wind dispersion from unprotected tips and mine tailings can be checked by either removal or covering with an uncontaminated layer of earth. Such sources should be rendered inaccessible to children. The management of contaminated soils and dusts in houses and villages adjacent to industrial sources is not generally amenable to simple measures. Paving with impervious material is expensive and aesthetically unsatisfactory. Treatment of earth surfaces with a resin or similar material in order to diminish wind dispersion may be temporarily effective, but cannot be applied to land used for the cultivation of crops. Frequently, the only solution is the physical removal and replacement of soil in the heavily contaminated inhabited area. However, there are as yet no generally agreed standards for the permissible lead content of surface soils in relation to dwellings or for other uses. Similar considerations apply to the permissible content of respirable lead in the atmosphere. It has been calculated that each $1 \mu \mathrm{g} / \mathrm{m}^{3}$ lead contributes approximately $1-2 \mu \mathrm{g} / 100 \mathrm{ml}$ to the content of lead in blood. There are as yet no generally agreed air quality standards, although values in the range $1-5 \mu \mathrm{g} / \mathrm{m}^{3}$ have been suggested. In the EEC countries a standard of $2 \mu \mathrm{g} / \mathrm{m}^{3}$ for residential areas remote from motorways and industry has been recommended, while the US Environmental Protection Agency has advocated $1.5 \mu \mathrm{g} / \mathrm{m}^{3}$ of air. It should be noted, however, that such standards are usually intended to apply to mean monthly or even annual values and that transient or seasonal fluctuations may occur.

\section{Conclusions}

There is no longer any reasonable doubt that acute lead encephalopathy and recurrent symptomatic 
plumbism in children can, in a high proportion of cases, result in severe residual CNS injury, including seizure, mental retardation, severely handicapping behavioural disorders and, in rare cases, blindness, and hemiparesis. In asymptomatic or mildly symptomatic plumbism, clinical studies have given conflicting results. There is some evidence, however, that a sustained $\mathrm{PbB}>50-60 \mu \mathrm{g} / 100 \mathrm{ml}$ during early childhood carries a significant risk of subtle neurobehavioural impairment, but not for the more serious sequelae associated with symptomatic lead poisoning. Such subtle deficits do not become evident until later in childhood. Data on immature animals also indicate that subtle cognitive and visual deficits, but not hyperactivity, may result when $\mathrm{PbB}$ is sustained in the $50-100 \mu \mathrm{g}$ range. The effects of unsustained increases of $\mathrm{PbB}$ in the same range are unknown. Concurrent marginal or frank nutritional deficiencies especially of iron, calcium, and zinc, as well as the habitual overuse of fat in the diet, may be important cofactors in determining the final clinical outcome. A thorough history to identify all potential sources of overexposure to lead in the child's environment, followed by identification of the actual sources is essential. Separation of the child from sources of lead constitutes the cornerstone of any therapeutic plan. Although the use of combined chelation treatment in acute lead encephalopathy can be life-saving, treatment started after the onset of severe symptoms will not prevent the occurrence of CNS sequelae in survivors. Modern screening tests permit the detection of plumbism before the onset of symptoms. The indications for the use of chelating agents in asymptomatic increased lead absorption are uncertain. Emphasis is placed on the need for individual management and long-term follow-up to determine the trends in each child's course. Pica, the response to assimilated lead, and the pattern of neurodevelopment during the first 3-4 years of postnatal life, may make the young child more vulnerable to overexposure to lead than older children and adults.

\section{Appendix: treatment of acute plumbism}

In acute lead encephalopathy, treatment with combined BAL-CaEDTA in the following dosage is recommended: BAL, $500 \mathrm{mg} / \mathrm{m}^{2}$ per $24 \mathrm{~h}$; CaEDTA, $1500 \mathrm{mg} / \mathrm{m}^{2}$ per $24 \mathrm{~h}$. To lessen pain, procaine is added to the $20 \%$ CaEDTA concentrate in a final concentration of $0.5 \%$. Each drug is given by deep IM injection at separate sites simultaneously in divided doses 4-hourly for 5 days. This is maximum dosage. It is unsafe to continue it beyond 5 days. In asymptomatic or very mildly symptomatic patients with confirmed $\mathrm{PbB}$ in excess of 80 to $100 \mu \mathrm{g}$, the above regimen may be modified as follows: discontinue BAL when used after 48 hours but continue CaEDTA for an additional 48 to 72 hours in reduced dosage of $1000 \mathrm{mg} / \mathrm{m}^{2}$ per day divided into two or three doses at 8- to 12-hour intervals. If CaEDTA is used alone in patients with initial PbB $<80$ to $100 \mu \mathrm{g}, 500 \mathrm{mg} / \mathrm{m}^{2}$ 12-hourly either by deep IM injection or by continuous IV infusion for 3 to 5 days should suffice. Patients receiving BAL should be placed on parenteral fluids or clear liquids orally to minimise the vomiting which BAL often causes. Brief courses of chelation treatment are virtually always associated with rebound in $\mathrm{PbB}$, presumably as a result of internal redistribution of lead (Fig. 6). When it is considered desirable to lessen this rebound and maintain soft tissue lead at a low level until the excess lead has been either excreted or well sequestered in bone, an initial course of CaEDTA, with or without BAL, may be followed by oral PCA. Oral PCA should be continued until FEP decreases to near normal. Even so, such patients must still be checked for delayed rebound in $\mathrm{PbB}$ and FEP. Although clinical studies are not available, experimental data strongly suggest that prophylactic amounts of iron, zinc, and copper should be given during long-term treatment with PCA to prevent depletion of these metals. Oral dosage of PCA

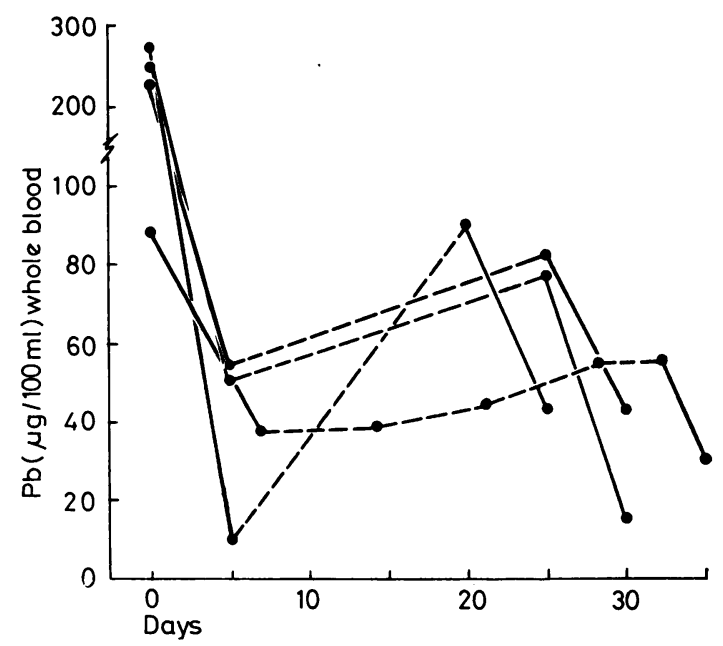

Fig. 6 Rebound in PbB between brief courses of chelation treatments.

These data were obtained in 4 children continuously in hospital for 30 to 40 days. The solid bars show the decrease in $P b B$ during 5-day courses of CaEDTA (or $B A L-C a E D T A$ ), while the broken lines show the upward trend in $\mathrm{PbB}$ between courses of chelating agents. Serial measurements of ALAD, ALAU, and $C P U$, but not FEP, show virtually identical trends. 
should not exceed $600 \mathrm{mg} / \mathrm{m}^{2}$ per day, given on an empty stomach in chilled fruit juice, if necessary, 2 hours before breakfast.

The use of combined BAL-CaEDTA treatment for acute lead encephalopathy is described in detail elsewhere (Chisolm, 1968). The salient points are: (1) appropriate supportive therapy is just as vital to survival as chelating agents, (2) BAL-CaEDTA therapy must be instituted promptly, (3) parenteral fluids are restricted to basal requirements and a minimal estimate of replacement of deficits caused by dehydration, protracted vomiting, or concurrent renal injury due to lead. Adequate, but not excessive urine flow must be established before CaEDTA can be given. Mannitol may be necessary to re-establish adequate urine flow. Initial control of seizures is perhaps best achieved by diazepam, while further convulsive activity should be controlled with paraldehyde until the patient is substantially improved, after which long-term anticonvulsant treatment with phenylhydantoin may be instituted.

Surgical decompression and hypertonic solutions to relieve intracranial pressure and reduce cerebral oedema are contraindicated. Time should not be wasted in attempts to evacuate residual lead from the bowel by enema. Such attempts are futile and the attendant delay jeopardises the child's life. In symptomatic children who do not have obvious evidence of increased intracranial pressure, it is judicious to treat them in hospital as possible incipient cases of encephalopathy and so monitor parenteral fluids and urine output and restrict oral intake during the initial 24 to 48 hours of treatment.

\section{References}

Albert, R. E., Shore, R. E., Sayers, A. J., Strehlow, C., Kneip, T. J., Pasternack, B. S., Friedhoff, A. J., Covan, F., and Cimino, J. A. (1974). Follow-up of children overexposed to lead. Environmental Health Perspectives, 7, 33-39.

Anku, V. D., and Harris, J. W. (1974). Peripheral neuropathy and lead poisoning in a child with sickle-cell anemia. Journal of Pediatrics, 85, 337-340.

Baker, E. L., Jr, Folland, D. S., Taylor, T. A., Frank, M., Peterson, W., Lovejoy, G., Cox, D., Housworth, J., and Landrigan, P. J. (1977). Lead poisoning in children of lead workers. Home contamination with industrial dust. New England Journal of Medicine, 296, 260-261.

Barltrop, D. (1966). The prevalence of pica. American Journal of Diseases of Children, 112, 116-123.

Barltrop, D., and Killala, N. J. P. (1967). Faecal excretion of lead by children. Lancet, 2, 1017-1019.

Barltrop, D., and Khoo, H. E. (1975). The influence of nutritional factors on lead absorption. Postgraduate Medical Journal, 51, 795-800.

Barltrop, D., Strehlow, C. D., Thornton, I., and Webb, J. S. (1975). Absorption of lead from dust and soil. Postgraduate Medical Journal, 51, 801-804.
Barltrop, D., and Strehlow, C. D. (1978). The absorption of lead by children. In Proceedings of the Third International Symposium on Trace Element Metabolism in Man and Animals, Freising, West Germany, July 1977. Edited by M. Kirchgessner. Institut für Ernahrungs Physiologie, Technische Univerität: München.

Barry, P. S. I. (1975). A comparison of concentrations of lead in human tissues. British Journal of Industrial Medicine, 32, 119-139.

Barton, J. C., Conrad, M. E., Harrison, L., and Nuby, S. (1978). Effects of calcium on the absorption and retention of lead. Journal of Laboratory and Clinical Medicine, 91, 366-376.

Beattie, A. D., Moore, M. R., Devenay, W. T., Miller, A. R., and Goldberg, A. (1972). Environmental lead pollution in an urban soft-water area. British Medical Journal, 2, 491-493.

Betts, P. R., Astley, R., and Raine, D. N. (1973). Lead intoxication in children in Birmingham. British Medical Journal, 1, 402-406.

Boeckx, R. L., Posti, B., and Coodin, F. J. (1977). Gasoline sniffing and tetraethyl lead poisoning in children. Pediatrics, 60, 140-145.

Bridbord, K. (1977). Human Exposure to Lead from Motor Vehicle Emissions. National Institute for Occupational Safety and Health Publication No. 77-145. Department of Health, Education, and Welfare: Atlanta.

Brown, D. R. (1975). Neonatal lead exposure in the rat: decreased learning as a function of age and blood lead concentrations. Toxicology and Applied Pharmacology, 32, 628-637.

Bushnell, P. J., Bowman, R. E., Allen, J. R., and Marlar, R. J. (1977). Scotopic vision deficits in young monkeys exposed to lead. Science, 196, 333-335.

Byers, R. K. (1959). Lead poisoning. Review of the literature and report on 45 cases. Pediatrics, 23, 585-603.

Byers, R. K., and Lord, E. E. (1943). Late effects of lead poisoning on mental development. American Journal of Diseases of Children, 66, 471-494.

Campbell, R. C., Brodie, M. J., Thompson, G. C., Meredith, P. A., Moore, M. R., and Goldberg, A. (1977). Alterations in the activity of enzymes of haem biosynthesis in lead poisoning and acute hepatic porphyria. Clinical Science and Molecular Medicine, 53, 335-340.

Chamberlain, A. C., Heard, M. J., Little, P., Newton, D., Wells, A. C., and Wiffen, R. D. (1978). Investigations into Lead from Motor Vehicles. AERE-R.9198. UK Atomic Energy Authority: Harwell.

Chisolm, J. J., Jr (1962). Aminoaciduria as a manifestation of renal tubular injury in lead intoxication and a comparison with patterns of aminoaciduria seen in other diseases. Journal of Pediatrics, 60, 1-17.

Chisolm, J. J., Jr (1968). The use of chelating agents in the treatment of acute and chronic lead intoxication in childhood. Journal of Pediatrics, 73, 1-38.

Chisolm, J. J., Jr (1970). Acute and chronic effects of lead on the kidney. Presented at Lead Effects Conference, Mayaguez, Puerto Rico, February 1970. Sponsored by University of Cincinnati-Kettering Laboratory.

Chisolm, J. J., Jr (1973). Management of increased lead absorption and lead poisoning in children. New England Journal of Medicine, 289, 1016-1018.

Chisolm, J. J. Jr (1978). Heme metabolites in blood and urine in relation to lead toxicity and their determination. Advances in Clinical Chemistry, 20, 225-265.

Chisolm, J. J., Jr, and Harrison, H. E. (1956). The exposure of children to lead. Pediatrics, 18, 943-958.

Chisolm, J. J., Jr, and Harrison, H. E. (1957). The treatment of acute lead encephalopathy in children. Pediatrics, 19, 2-20. 
Chisolm, J. J., Jr, Barrett, M. B., and Mellits, E. D. (1975). Dose-effect and dose-response relationships for lead in children. Journal of Pediatrics, 87, 1152-1160.

Chisolm, J. J., Jr, Mellits, E. D., and Barrett, M. B. (1976). Interrelationships among blood lead concentration, quantitative daily ALA-U, and urinary lead output following calcium EDTA. In Effects and Dose-Response Relationships of Toxic Metals, pp 416-433. Edited by G. F. Nordberg. Elsevier: Amsterdam.

Clasen, R. A., Hartman, J. F., Starr, A. J., Coogan, Ph. S., Pandolfi, S., Laing, J., Becker, R., and Hass, G. U. (1974). Electron microscopic and chemical studies of the vascular changes and edema of lead encephalopathy. American Journal of Pathology, 74, 215-240.

Coffin, R., Phillips, J. L., Staples, W. I., and Spector, S. (1966). Treatment of lead encephalopathy in children. Journal of Pediatrics, 69, 198-206.

Creason, J. P., Hinners, T. A., Bumgarner, J. E., and Pinkerton, C. (1975). Trace elements in hair, as related to exposure in metropolitan New York. Clinical Chemistry, 21, 603-612.

Crosby, W. H. (1977). Lead-contaminated health food Association with lead poisoning and leukemia. Journal of the American Medical Association, 237, 2627-2629.

David, O., Clark, J., and Voeller, K. (1972). Lead and hyperactivity. Lancet, 2, 900-903.

de la Burdé, B., and Choate, M. S. (1975). Early asymptomatic lead exposure and development at school age. Journal of Pediatrics, 87, 638-642.

Dillon, H. K., Wilson, D. J., and Schaffner, W. (1974). Lead concentrations in human milk. American Journal of Diseases of Children, 128, 491-492.

Dobbing, J., and Smart, J. L. (1974). Vulnerability of developing brain and behaviour. British Medical Bulletin, 30, 164-168.

Emmerson, B. T. (1968). The clinical differentiation of lead gout from primary gout. Arthritis and Rheumatism, 11, 623-634.

Erenberg, G., Rinsler, S. S., and Fish, B. G. (1974). Lead neuropathy and sickle cell disease. Pediatrics, 54, 438441.

Feldman, R. G. (1978). Urban lead mining: lead intoxication among deleaders. New England Journal of Medicine, 298, 1143-1145.

Gafafer, W. M. (1966). Occupational Diseases-A Guide to Their Recognition. Public Health Service Publication No. 1097, pp. 170-172. United States Public Health Service: Washington DC.

Galke, W. A., Hammer, D. I., Keil, J. E., and Lawrence, S. W. (1975). Environmental determinants of lead burdens in children. In International Conference on Heavy Metals in the Environment, Toronto, Ontario, Canada, October 1975 , pp. 53-74.

Goyer, R. A. (1978). Calcium and lead interactions: some new insights. Journal of Laboratory and Clinical Medicine 91, 363-365.

Granick, J. L., Sassa, S., and Kappas, A. (1978). Some biochemical and clinical aspects of lead intoxication. Advances in Clinical Chemistry, 20, 287-339.

Grant, L. D., Kimmel, C. A., Martinez-Vargas, C. M., and West, G. L. (1976). Assessment of developmental toxicity associated with chronic lead exposure. Environmental Health Perspectives, 17, 290.

Hanna, T. L., Ditzler, D. N., Smith, C. H., Gupta, S., and Zarkowsky, H. S. (1976). Erythrocyte porphyrin analysis in the detection of lead poisoning in children. Clinical Chemistry, 22, 161-168.

Harris, R. W., and Elsea, W. R. (1967). Ceramic glaze as a source of lead poisoning. Journal of the American Medical Association, 202, 544-546.
Henderson, D. A., and Inglis, J. A. (1957). The lead content of bone in chronic Bright's disease. Australasian Annals of Medicine, 6, 145-154.

Kehoe, R. A. (1961). The metabolism of lead in man in health and disease. The Harben lectures 1960. Journal of the Royal Institute of Public Health and Hygiene, 24, 101-120, 129-143, 177-203.

Klein, M., Namer, R., Harpur, E., and Corbin, R. (1970). Earthenware containers as a source of fatal lead poisoning. Case study and public-health considerations. New England Journal of Medicine, 283, 669-672.

Koller, M-E., Romslo, L., Finne, P. H., Brockmeier, F., and Tyssebotn, I. (1978). The diagnosis of iron deficiency by erythrocyte protoporphyrin and serum ferritin analyses. Acta paediatrica Scandinavica, 67, 361-366.

Kotok, D., Kotok, R., and Heriot, J. T. (1977). Cognitive evaluation of children with elevated blood lead levels. American Journal of Diseases of Children, 131, 791-793.

Landrigan, P. J., Gehlbach, S. H., Rosenblum, B. F., Shoults, J. M., Candelaria, R. M., Barthel, W. F., Liddle, J. A., Smrek, A. L., Staehling, N. W., and Sanders, J. F. (1975). Epidemic lead absorption near an ore smelter. The role of particulate lead. New England Journal of Medicine, 292, 123-129.

Landrigan, P. J., Baker, E. L., Jr, Feldman, R. G., Cox, D. H., Eden, K. V., Orenstein, W. A., Mather, J. A., Yankel, A. J., and von Lindern, I. H. (1976). Increased lead absorption with anemia and slowed nerve conduction in children near a lead smelter. Journal of Pediatrics, 89, 904-910.

Lansdown, R. G., Shepherd, J., Clayton, B. E., Delves, H. T., Graham, P. J., and Turner, W. C. (1974). Bloodlead levels, behaviour, and intelligence: a population study. Lancet, 1, 538-541.

Lepow, M. L., Bruckman, L., Rubino, R. A., Markowitz, S., Gillete, M., and Kapish, J. (1974). Role of airborne lead in increased body burden of lead in Hartford children. Environmental Health Perspectives, 7, 99-102.

Lightfoote, J., Blair, H. J., and Cohen, J. R. (1977). Lead intoxication in an adult caused by Chinese herbal medication. Journal of the American Medical Association, 238, 1539.

Lourie, R. S., Layman, E. M., and Millican, F. K. (1963). Why children eat things that are not food. Children, 10, 143-146.

McCabe, L. J., Symons, J. M., Lee, R. D., and Robeck, G. G. (1970). Survey on community water supply systems. Journal of the American Waterworks Association, 62, 670-687.

McNeil, J. L., Ptasnik, J. A., and Croft, D. B. (1975). Evaluation of long-term effects of elevated blood lead concentrations in asymptomatic children. Archives of Industrial Hygiene and Toxicology, 26, Supplement, 97118.

Mahaffey, K. R. (1977). Relation between quantities of lead ingested and health effects of lead in humans. Pediatrics, 59, 448-456.

Mahaffey, K. R., Stone, C. L., Banks, T. A., and Reed, G. (1978). Reduction in tissue storage of lead in the rat by feeding diets with elevated iron concentration. In Proceedings of the Third International Symposium on Trace Element Metabolism in Man and Animals. Freising, West Germany, July 1977. Edited by M. Kirchgessner. Institut für Ernahrungs Physiologie, Technische Univerität: München.

Mitchell, D. G., and Aldous, K. M. (1974). Lead content of foodstuffs. Environmental Health Perspectives, 7, 59-64.

Moore, M. R. (1975). Lead and the mitochondrion. Postgraduate Medical Journal, 51, 760-764, 774-775. 
Natelson, E. A., and Fred, H. L. (1976). Lead poisoning from cocktail glasses. Observations on two patients. Journal of the American Medical Association, 236, 2527.

National Academy of Sciences Committee on Biologic Effects of Atmospheric Pollutants (1972). Lead. Airborne Lead in Perspective. The Academy: Washington DC.

National Academy of Sciences/National Research Council (1976). Recommendations for the Prevention of Lead Poisoning in Children. The Academy: Washington DC.

National Academy of Sciences/National Research Council (1977). Drinking Water and Health. The Academy: Washington DC.

Needleman, H. L., Gunnoe, C., Leviton, A., and Peresie, H. (1978). Neuropsychological dysfunction in children with 'silent' lead poisoning (abstract). Pediatric Research, $12,374$.

$\mathrm{Ng}$, R., and Martin, D. J. (1977). Lead poisoning from leadsoldered electric kettles. Canadian Medical Association Journal, 116, 508-509, 512.

Nordberg, G. F. (1976). Effects and Dose-Response Relationships of Toxic Metals. Elsevier: New York.

Nye, L. J. J. (1929). An investigation of the extraordinary incidence of chronic nephritis in young people in Queensland. Medical Journal of Australia, 2, 145-159.

Perkins, K. C., and Oski, F. A. (1976). Elevated blood lead in a 6-month old breast-fed infant: the role of newsprint logs. Pediatrics, 57, 426-427.

Perlstein, M. A., and Attala, R. (1966). Neurologic sequelae of plumbism in children. Clinical Pediatrics, 5, 292298.

Prasad, A. S., Schoomaker, E. B., Ortega, J., Brewer, G. J., Oberleas, D., and Oelshlegel, F. J., Jr (1975). Zinc deficiency in sickle cell disease. Clinical Chemistry, 21, 582-587.

Pueschel, S. M., Kopito, L., and Schwachman, H. (1972). Children with an increased lead burden: a screening and follow-up study. Journal of the American Medical Association, 222, 462-466.

Rabinowitz, M. B., Wetherill, G. W., and Kopple, J. D. (1976). Kinetic analysis of lead metabolism in healthy humans. Journal of Clinical Investigation, 58, 260-270.

Reigart, J. R., and Whitlock, N. H. (1976). Longitudinal observations of the relationship between free erythrocyte porphyrins and whole blood lead. Pediatrics, 57, 54-59.

Reiter, L. W., Anderson, G. E., Laskey, J. W., and Cahill, D. F. (1975). Developmental and behavioural changes in the rat during chronic exposure to lead. Environmental Health Perspectives, 12, 119-123.

Rosen, J. F., Zarate-Salvador, C., and Trinidad, E. E. (1974). Plasma lead levels in normal and lead-intoxicated children. Journal of Pediatrics, 84, 45-48.

Rummo, J. H. (1974). Intellectual and behavioural effects of lead poisoning in children. Ph.D thesis, University of North Carolina.

Seto, D. S. Y., and Freeman, J. M. (1964). Lead neuropathy in childhood. American Journal of Diseases of Children, 107, 337-342.

Sitarz, A. (1975). Severe lead poisoning in a 6-month old infant. Journal of Pediatrics, 86, 810-821.

Sorrell, M., Rosen, J. F., and Roginsky, M. (1977). Interactions of lead, calcium, vitamin $\mathrm{D}$, and nutrition in lead-burdened children. Archives of Environmental Health, 32, 160-164.

Stockman, J. A., III, Weiner, L. S., Simon, G. E., Stuart,
M. J., and Oski, F. A. (1975). The measurement of free erythrocyte porphyrin (FEP) as a simple means of distinguishing iron deficiency from beta-thalassemia trait in subjects with microcytosis. Journal of Laboratory and Clinical Medicine, 85, 113-119.

Strehlow, C. D., and Barltrop, D. (1978). Nutritional status of lead exposure in a multiracial population. Twelfth Annual Conference on Trace Substances in Environmental Health, June 1978. University of Missouri: Columbia, Missouri.

Tepper, L. B. (1963). Renal function subsequent to childhood plumbism. Archives of Environmental Health, 7, 76-85.

ter Haar, G., and Aronow, R. (1974). New information on lead in dirt and dust as related to the childhood lead problem. Environmental Health Perspectives, 7, 83-89.

United States Public Health Service (1978). Statement: Preventing Lead Poisoning in Young Children. Center for Disease Control: Atlanta.

Valentine, W. N., Paglia, D. E., Fink, K., and Madokoro, G. (1976). Lead poisoning. Association with hemolytic anemia, basophilic stippling, erythrocyte pyrimidine 5' nucleotidase deficiency, and intraerythrocytic accumulation of pyrimidines. Journal of Clinical Investigation, 58, 926-932.

Vallee, B. L., and Ulmer, D. D. (1972). Biochemical effect of mercury, cadmium, and lead. Annual Review of Biochemistry, 41, 91-128.

Vostal, J. J., Taves, E., Sayre, J. W., and Charney, E. (1974). Lead analysis of house dust: a method for the detection of another source of lead exposure in inner city children. Environmental Health Perspectives, 7, 91-97.

Wada, O., Yano, Y., Toyokawa, K., Suzuki, T., Suzuki, S., and Katsunuma, H. (1972). Human responses to lead; in special reference to porphyrin metabolism in bone marrow erythroid cells and clinical and laboratory study. Industrial Health, 10, 84-92.

Warley, M. A., Blackledge, P., and O'Gorman, P. (1968). Letter: Lead poisoning from eye cosmetic. British Medical Journal, 1, 117

Wigle, D. T., and Charlebois, E. J. (1978). Electric kettles as a source of human lead exposure. Archives of Environmental Health, 33, 72-78.

Williams, H., Schulze, W. H., Rothschild, H. B., Brown, A. S., and Smith, F. R., Jr (1933). Lead poisoning from the burning of battery casings. Journal of the American Medical Association, 100, 1485-1489.

Wolf, M. D. (1973). Lead poisoning from restoration of old homes. Journal of the American Medical Association, 225, 175-176.

World Health Organisation (1977). Environmental Health Criteria. 3. Lead. WHO: Geneva.

Yankel, A. J., von Lindern, I. H., and Walter S. D. (1977) The Silver Valley lead study. The relationship between childhood blood lead levels and environmental exposure. Journal of the Air Pollution Control Association, 27, 763-767.

Ziegler, E. E., Edwards, B. B., Jensen, R. L., Mahaffey, K. R., and Fomon, S. J. (1978). Absorption and retention of lead by infants. Pediatric Research, 12, 29-34.

Correspondence to Dr Donald Barltrop, Westminster Children's Hospital, Department of Child Health, Vincent Square, London SW1P 2NS. 